\title{
Bioenergy production capacity in the province of Santa Fe, Argentina
}

\author{
Sergio Montico \\ Facultad de Ciencias Agrarias, Universidad Nacional de Rosario, CC 14 - S2125ZAA Zavalla, Argentina
}

\begin{abstract}
S. Montico. 2009. Bioenergy production capacity in the province of Santa Fe, Argentina. Cien. Inv. Agr. 36(32):465-474. Bioenergy is a renewable source of primary energy and its sustainable use is an advantage to the current global energy crisis. The use of vegetable resources for energy purposes requires specific studies of the impacts that might occur to the economy and the environment. The province of Santa Fe (Argentina) has an agroproductive structure capable of providing biomass for its processing and production of energy. The objective of this work was to value the capacity of this province for bioenergy production from grains transformation into biofuels and the biomass energy from crop straw, and speculates on the impact on soils from removed crop residues. Crop residues of the ten most important grain and oilseed crops $\left(15.2 \times 10^{6} \mathrm{Mg}\right.$ year $\left.{ }^{-1}\right)$ and bioethanol and biodiesel from soybeans and corn, would provide $295,383 \mathrm{TJ}$. The residues would provide potentially $72.1 \%\left(32.4 \times 10^{6} \mathrm{DB}\right.$, $282.9 \mathrm{PJ}$ or $45.6 \times 10^{12} \mathrm{kcal}$ ) and biofuels $27.9 \%$. The removal of residues for this purpose would have risky consequences for the sustainability of agricultural productivity, particularly on soil conservation and stability of production systems. There is a further exploration of alternative sources such as bioenergy crop plantations or shrub or tree species, rather than the use of crop residues.
\end{abstract}

Key words: Biofuels, bioenergy, crops residues, sustainability.

\section{Introduction}

Bioenergy is a renewable source of primary energy whose sustainable use does not emit carbon dioxide, and as such, it represents an opportunity for supplying energy globally (Graham et al., 2007). In turn, it involves opportunities as well as risks. The implications of bioenergy for safe feeding and the environment depend on the scale and speed of change, as well as the type of system to be regarded, the structure of the products and energy markets, and the decisions on energy, agricultural, environmental and commercial politics (FAO, 2006).

Received 9 March 2009. Accepted 13 July 2009. Corresponding author: smontico@unr.edu.ar
The use of vegetal resources with energy purposes creates pressure on grassland areas, native forests and protected areas, as well as an intensification of production on the current worked areas. This leads to a specific in situ study as for offer factors as the energy demand. The potential bioenergy production in Argentina is extremely important due to its characteristic current matrix energy, and by its comparative advantages for the production of biological energy vectors from several sources (Secretaría de Energía Argentina, 2008).

The harvest residues are an important source of forage and energy (Fischer and Schrattenholzer, 2001), the use of these materials as biorefinery imput to obtain energy represents a great deal of concern for the decision makers of the world 
(NREL, 2006). On the other hand, grains production represents a source of bioenergy, because it is feasible to obtain biofuels from their processing, resources relatively new that are becoming part of the matrix energy of the developed and developing countries (Mae-Wan et al., 2006).

In Argentina, Law 26.093 will be valid since 2010 (SAYDS, 2009), which provides a regime of regulation and promotion for the production and sustainable use of biofuels for fifteen years, and establishes the mixture of gas oil or diesel oil and nafta with 5\% of biodiesel and bioethanol, respectively. These and other measurements adopted at governmental level will allow the country to promote its comparative advantages in comparison to the Northern countries, especially in biodiesel production, and although late, the technological innovations and the low costs, in regard to the scale, to show superiority on soybean based biodiesel (Mathews and Goldsztein, 2009). However, and according to Lamers et al., (2008) when analyzing the Argentinean market of liquid biofuels, revealed that there are important differences regarding the future opportunities of bioethanol and biodiesel, and that biodiesel based on soybean does not seem to be a sustainable option.

Recent studies show that an increase on the world demand for biofuels may involve a price increase of cultivations energy, increase on the price of traditional cultivations and a reduction on the price of biofuels byproducts (Razo et al., 2007).

Stover and cultivations grains are resources of great value not only from the view of energy, but also from the soils protection and food production perspective (Montico et al., 2007). There is a growing concern for soils and environment conservation, when harvest residues are considered to be assigned for obtaining energy (Lal and Pimentel, 2007). Dispensing with this input of natural origin in agroecosystems would represent important and serious implications on territorial sustainability.

In this work, the capacity of the province of Santa Fe for bioenergy production is valued, from transforming grains and the biomass from cultivations stover into biofuels, and the impact on soils that the extraction of harvest residues would exert is speculated.

\section{Materials and Methods}

The province of Santa Fe has a surface of $133.007 \mathrm{~km}^{2}, 3,54 \%$ of the Argentinian territory. Its geographical location $\left(28^{\circ}\right.$ and $34^{\circ} 22^{\prime}$ lat $\mathrm{S}$ and $58^{\circ}$ and $62^{\circ} 52^{\prime}$ long W), availability of natural resources and productive infrastructure, outstand as a highly relevant agroindustrial center at territorial level. The main production of cereals and oleaginous plants from Santa Fe cultivations represents around $15 \%$ of the total in the country (Stock Market of Santa Fe, 2009).

The matrix energy of the province is based on the use of fossil fuels and it is including plants to obtain first generation biofuels for the few last years, most of them for export. Santa Fe could become in an important region for producing and processing grains as well as cultivation residues, because of its capacity of cereals and oleaginous production, and therefore, strengthen its potential bioenergy. This possible future rank would place it in a privileged position not only at national level but also internationally.

Nevertheless, that strength could involve a great weakness when balancing the benefits along with the harms caused by the redirection of all the biomass production to the processing plants to obtain energy, mainly in the case of the cultivations residues. The situation would become, at least, risky, because depriving the Santa Fe soils from stover, subject to a specifically agricultural production, would involve a serious danger for the agroecosystems sustainability.

In order to evaluate the capacity of the province of Santa Fe to obtain biomass energy from residues of cultivations and biofuels, mainly biodiesel and bioethanol, a recount of products and their energy conversion was elaborated. From data of the Stock Market of Santa Fe (2009) the harvested surface and the physical yield of the main cultivations produced in the 2002-2007 campaigns was obtained. Such pe- 
riod was adopted because it comprises dry and humid years, inclusion of new technology and influence of international markets.

The physical production of the ten most representative cultivations of cereals and oleaginous was transformed into residues values through [1].

Residues production $=$ Grains production of $\mathrm{x}$ residue/grain ratio [1]

because the residue/grain ratio has variations per species, genotype, environment and applied technology, the values proposed by several authors were averaged (Gupta et al., 1979; Larson et al., 1982; Strehler and Stutzle, 1987; Stout, 1990; Lal, 1995).

The residues production was transformed into energy. The fuel value of $1 \mathrm{mg}$ of harvest resi- dues is estimated in $18,6 \times 10^{9} \mathrm{~J}, 2$ diesel barrels (DB) or $3 \times 10^{6} \mathrm{kcal}(\mathrm{Lal}, 1995)$.

In regard to the grains, they may be treated by industrial processes able to transform them into fuels by the known first generation technology. In the case of soybean (Glicyne max $L$. Merr.), biodiesel is obtained through oil transesterification with methylic alcohol in a basic environment; bioethanol is produced directly with from maize sugar (Zea mays L.) distillation and transformation (fermentation) and further dehydration.

The potential energy contribution from maize and soybean grains able to generate as biofuel in the territory analyzed, was obtained by equivalent units (Pimentel, 2003; Mae-Wan et al., 2006) and the further conversion through their energy content (Patzek and Pimentel, 2005; NCCE, 2008) (Table 1).

Table 1. Total harvested area and proportionate, average yield and grain harvested from the ten most important crops in Santa Fe.

\begin{tabular}{lllll}
\hline Crop & $\begin{array}{l}\text { Area } \\
\text { harvested } \\
(\mathrm{ha})\end{array}$ & $\%$ & $\begin{array}{l}\text { Yield } \\
\text { Average } \\
\left(\mathrm{mg} \mathrm{ha}^{-1}\right)\end{array}$ & $\begin{array}{l}\text { Grain } \\
\text { harvested } \\
(\mathrm{mg})\end{array}$ \\
\hline Lino (Linux usitatissimun L.) & 675 & 0,01 & 1.22 & 824 \\
Sunflower (Helianthus annuus) & 164,500 & 3.33 & 1.95 & 320,650 \\
Cotton (Gossypium hirsutum) & 8,545 & 0.17 & 1.62 & 13,860 \\
Soybean (Glycine max L.) & $3,624,318$ & 73.30 & 2.58 & $9,340,516$ \\
Wheat (Triticum aestivum) & 697,380 & 14.10 & 2.36 & $1,647,240$ \\
Barley (Hordeum vulgare) & 3,920 & 0.08 & 2.82 & 11,050 \\
Corn (Zea mays) & 306,870 & 6.21 & 6.84 & $2,098,472$ \\
Rice (Oryza sativa L.) & 15,900 & 0.32 & 4.52 & 71,800 \\
Millet (Panicum mileaceum) & 1,209 & 0.02 & 2.24 & 2,709 \\
Sorghum (Sorghum bicolor L.) & 121,340 & 2.45 & 4.44 & 539,140 \\
Total & $4,944,657$ & 100.00 & & $14,046,261$ \\
\hline
\end{tabular}

\section{Results and discussion}

The surface harvested in Santa Fe is $21 \%$ of the surface harvested in Argentina (Stock Market of Santa Fe, 2009). Soybean, wheat and maize, represent $93,6 \%$ of the total harvested surface in the province $(73,3 \%, 14,1 \%$ and $6,2 \%$, respectively) and the harvested grains /harvested surface ratio is 2,84 (Table 2).
Table 2. Dry weight relation of straw and the grain crop.

\begin{tabular}{lc}
\hline Crop & straw: grain \\
\hline Linen & 1.20 \\
Sunflower & 1.00 \\
Cotton & 1.50 \\
Soybean & 1.00 \\
Wheat & 1.50 \\
Barley & 1.50 \\
Corn & 1.00 \\
Rice & 1.57 \\
Millet & 1.60 \\
Sorghum & 1.53 \\
\hline
\end{tabular}


The approximate amount of residues is different between cultivations. The harvest residues vary widely in their properties and in decomposition rates. The main causes of the variability in the estimations are related to the annual changes on cultivation rotations and the residue/grain ratios (Stout, 1990; Lal, 1995).

The ratios between the grains and residues production for the ten most representative cultivations in Santa Fe are detailed in Table 3.

Table 3. Energy value of the residues produced by the ten most important crops in Santa Fe.

\begin{tabular}{llll}
\hline Crop & $\begin{array}{l}\text { Residues } \\
(\mathrm{mg})\end{array}$ & $\%$ & $\begin{array}{l}\text { Energy } \\
\text { value } \\
(\mathrm{TJ})\end{array}$ \\
\hline Lino & 989 & 0.01 & 18.4 \\
Girasol & 320,650 & 2.11 & $5,964.1$ \\
Algodón & 20,790 & 0.14 & 386.7 \\
Soja & $9,340,516$ & 61.41 & $173,733.6$ \\
Trigo & $2,470,860$ & 16.24 & $45,958.0$ \\
Cebada & 16,575 & 0.11 & 308.3 \\
Maíz & $2,098,472$ & 13.80 & $39,031.6$ \\
Arroz & 112,726 & 0.74 & $2,096.7$ \\
Mijo & 4,334 & 0.03 & 80.6 \\
Sorgo & 824,884 & 5.42 & $15,342.8$ \\
Total & $15,210,796$ & 100.00 & $282,902.4$ \\
\hline
\end{tabular}

The total production of cultivations residues at world level is estimated in $3,8 \times 10^{12} \mathrm{Mg}$ year ${ }^{-1}$, from which $74 \%$ corresponds to cereals, $8 \%$ to legumes, $3 \%$ to oleaginous cultivations, $10 \%$ to sugar cultivations and 5\% to tubers ( Lal, 2005). For example, the United States has a total residues production of $488 \times 10^{6} \mathrm{Mg}$ year $^{-1}$ and $75 \%$ is concentrated in four cereals: maize, wheat, rice and sorghum (Lal, 2005). Due to their agroproductive profile, these proportions change in Santa Fe (Table 4). Cultivations that are regarded oleaginous (flax, sunflower, cotton and soybean) generate $9.682 .945 \mathrm{Mg}$ year $^{-1}(63,7 \%)$ and cereals (wheat, barley, maize, rice, millet and sorghum) $5.527 .851 \mathrm{Mg}$ year $^{-1}(36,3 \%)$.
Table 4. Equivalent values of energy from crop residues in Santa Fe.

\begin{tabular}{ll}
\hline Parameter & Santa Fe \\
\hline Crops residues $\left(10^{6} \mathrm{mg}^{\left.-y_{e}{ }^{-1}\right)}\right.$ & 15.2 \\
Oil equivalent $\left(10^{6} \mathrm{BD}\right)$ & 32.4 \\
Energy equivalent & \\
\multicolumn{1}{c}{ Petajoules $\left(10^{15} \mathrm{~J}\right)$} & 282.9 \\
$10^{12} \mathrm{kcal}$ & 45.6 \\
\hline
\end{tabular}

The energy content of the residues varies between the species cultivated, thus, Stout (1990) differentiates the energy content of rice straw (3.015 kcal kg-1) from hey from other gramineae $\left(3.738 \mathrm{kcal} \mathrm{kg}^{-1}\right)$. The approximate fuel value per $\mathrm{Mg}$ of harvest residues is 2 diesel barrels (DB), $18,6 \times 10^{9} \mathrm{~J}$ o $3 \times 10^{6} \mathrm{kcal}$ (Lal, 1995). The energy values corresponding to the cultivation residues analyzed are observed in Table 3 (in Terajoules $=10^{12}$ Joules). The two summer cultivations providing more energy annually are soybean and maize $(212.765,2 \mathrm{TJ})$, with wheat being the winter cultivation that generates higher energy potential $(16,2 \%)$.

Some agronomists and economists state that not all cultivations should be regarded in the recount of residues production to obtain bioenergy, because of the intricate final arrangement after harvest (cotton) or a relatively rapid degradation (soybean) (Lal, 2005).

In regard to the estimations of $\mathrm{Mg}$ conversion of harvest residues to oil barrels, Joules or kcal, the energy equivalents are shown in Table 5.

Table 5. Biodiesel and bioethanol amount and energy potentially obtained from soybeans and corn.

\begin{tabular}{|c|c|c|c|c|c|}
\hline Biodiesel & of Soybean & & Bioetanol & of Corn & \\
\hline $\mathrm{Mg}$ & $\mathrm{L}^{(1)} \times 10^{3}$ & $\mathrm{TJ}^{(3)}$ & $\mathrm{Mg}$ & $\mathrm{L}^{(2)} \times 10^{3}$ & $\mathrm{TJ}^{(4)}$ \\
\hline $9,340,516$ & $1,868,103.2$ & $64,449.5$ & $2,098,472$ & $776,434.6$ & $18,168.6$ \\
\hline
\end{tabular}


A comparative dimension may be accomplished through the relation of these parameters with two highly contrasting situations and scales: the American economy on the one hand, and the Zimbawe economy (Africa) on the other. For similar products, the energy value of the harvest residues produced per year is $9.100 \mathrm{PJ}$ in the first (Lal, 2005), and 81,5 PJ in the second (Jingura and Matengaifa, 2008).

As the production of soybean and maize grains represents approximately $81,4 \%$ of the total in the province, it is proposed the estimation of the potential energy contribution provided by biodiesel and bioethanol through the grain/biofuel/ energy transformation.

From the total contribution of energy from both biofuels $(82,618.1 \mathrm{TJ}), 78 \%$ corresponds to biodiesel and $22 \%$ to bioethanol. It is of interest to know the energy that could be generated in the province of Santa $\mathrm{Fe}$ when these residues, as well as the biofuels obtained from the two most harvested cultivations $(79.5 \%)$, soybean and maize, are used. This is, to assign all the grains and stover production to the local energy matrix or eventually for export.

The potential contribution of energy from both cultivations, 238,183 TJ and 57,200 TJ for soybean and maize, respectively, is shown in Figure 1. The residues would contribute with $72.1 \%$, and biofuels with $27.9 \%$.

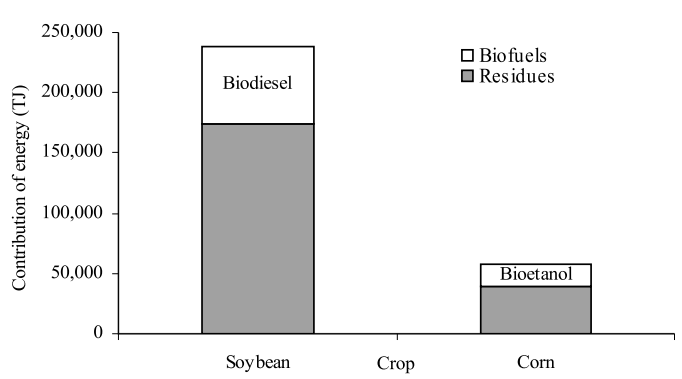

Figure 1. Energy provided by the residues and biofuels obtained from soybeans and corn.
Consequently, due to the relative importance of biomass from harvest residues (cranes, leaves, marlos, heads, etc) as energy source for biofuels, they could be extracted from the settlements and transform effectively into energy. This is where the core of the discussion arises, focused mainly on the appropriateness of such allocation.

Stovers are a valuable resource of limited generation, with a direct and indirect influence on systems of agropecuarian production (Mann et al., 2002; Lal and Pimentel, 2007). Therefore, Wilhelm et al. (2004) and Lal (2005) state that their indiscriminate elimination could lead to a decrease in soils quality with adverse impacts on the environment in the long term. The return of harvest residues improves the soil quality through the reduction of erosion risks, storage and recycling of nutrients, the stability of the structure, the reduction of density and the improvement of conditions of water retention and transmission, providing also energy for microbial processes, and in the long term, helping to increase the agronomic productivity.

Nevertheless, some investigations are less strict. Nelson (2002) and Shehan et al. (2004) state for example, that in Iowa (U.S.A.), around $40 \%$ of maize residue in conventional agriculture and up to $70 \%$ in direct sowing may be assigned to energy production, maintaining the risks of erosion under the tolerable limits, and Graham et al. (2007) indicate that the extraction may be balanced.

In regard to the relevance of residues conservation to fulfill edaphic processes and functions, several investigators warn on the implications of their elimination. Quiroga et al. (1998) and Wilhelm et al. (2004) warn on the risks of diminishing the organic matter in soil, which in turn reduces aggregation, affecting negatively the structural stability (Andriulo and Cordone, 1998; Carter, 2002). Mubarak et al. (2002) and García (2007) speculate on the damage caused 
by the lower availability of macronutrients $(\mathrm{N}$, $\mathrm{P}, \mathrm{K})$ and micronutrients $(\mathrm{S}, \mathrm{Cu}, \mathrm{B}, \mathrm{Zn}, \mathrm{Mo})$, which are necessary for cultivations growth. In addition, Franzluebbers (2002) states that harvest residues sustain energetically the edaphic microbial processes, essential for forming and stabilizing aggregates and nutrients recycling.

On the other hand, there is clear evidence on the yield decrease of cultivations by the continuous elimination of harvest residues (Linden et al.; 2000). Wilhelm et al. (2004) in Nebraska, USA, informed that the grain yield of the following cultivations decreased in $0.13 \mathrm{mg} \mathrm{ha}^{-1}$. year ${ }^{-1}$ per each $\mathrm{mg}$ of extracted maize residue, and Alvarez and Barraco (2005) in Northern Buenos Aires, Argentina, reported favorable impacts on yields of summer cultivations when the soil is covered with important amounts of stover. Likewise, or more important, it is the role that the residues have against the growing world problem of the greenhouse effect. The remaining 6 to $8 \mathrm{tha}^{-1}$ of harvest residues with the practice of direct sowing may sequestrate $\mathrm{C}$ in soil in a 500-1.000 kg C ha-1 year ${ }^{-1}$ ratio (Lal et al., 1999). The main components of $\mathrm{C}$ cycle are along the soil organic matter and affect directly the atmospherical $\mathrm{CO}_{2}$ concentration (Alvarez, 2001; Lal, 2004).

As categorically indicated by Lal and Pimentel (2007), the massive elimination of cultivations residues to obtain energy would worsen the risks of soil degradation, affecting the environment, diminishing the agronomic productivity and turning into an unsustainable agriculture. Maybe if the proportion assigned to that purpose is balanced, the objective becomes satisfactory (Blanco-Canqui and Lal, 2006; Nonhebel, 2007), or maybe, by optimizing the technology of biomass transformation, the possibilities are environmentally less conflictive. The problem to be solved is focused on the high cost of residues collection in extensive productive systems, the mobilization of high volumes of slightly dense material and the further compaction for processing (Patrouilleau et al., 2006).
A feasible alternative is implanting the so called annual or perennial bioenergy cultivations or plants, natural or adapted, in areas of low agronomic aptitude of the province, without affecting consequently the best soils to obtain processable biomass. In such a case, some are: African Guinea Grass (Panicum maximum), Elephant Grass (Pennisetum purpureum) or setaria (Setaria sphcelate). In addition to the cultivations and plants mentioned before, in Santa $\mathrm{Fe}$ it is possible to resort to the implantation of forest species as poplars (Populus ssp.), willows (Salix ssp.), pines (Pinus ssp.) and eucaliptus (Eucalyptus ssp.), assigned to obtain ethanol with cellulosic base. It is noteworthy that when the biomass is from other cellulose sources which are not grains, the energy balance and the final energy yield are higher, as well as the reduction of emissions of greenhouse gases (Argonne National Laboratory, 2005). Giunta (2007) considers that, except by around $40 \%$ of the surface occupied with high aptitude soils in Santa Fe (5.2 x $10^{6} \mathrm{ha}$ ), it might be feasible to obtain energy from cultivated biomass with less economical and environmental risk.

The harvest residues from the dominant cereals and oleaginous plants currently represent the most important potential bioenergy source from agriculture of the province, even more than biofuels from the transformation of soybean and maize grains. Thus, Santa Fe will have a significant amount of energy to be included in the local matrix energy, if the administration decides to obtain it from this biomass. But, this would become a serious risk for the agroecosystems sustainability, as they are relevant for maintaining the soils quality, for functions as for ecological processes. The economical benefits would be widely exceeded by the environmental damages associated to this method for obtaining energy. It becomes necessary to provide a deeper insight on the exploration of more alternative sources as bioenergy cultivations or plantations of bushlike or tree species, instead of the use of harvest residues. 


\title{
Resumen
}

\begin{abstract}
S. Montico. 2009. Potencial bioenergético de la provincia de Santa Fe, Argentina. Cien. Inv. Agr. 36(3): 465-474. La bioenergía es una fuente renovable de energía primaria y su uso sostenible representa una ventaja ante la actual crisis energética mundial. La utilización de recursos vegetales con fines energéticos requiere de estudios específicos por los impactos que podrían ocasionarse a la economía y al ambiente. La provincia de Santa Fe (Argentina), posee una estructura agroproductiva capaz de proveer biomasa para su procesamiento y obtención de energía. Los residuos de cosecha de los diez cultivos de cereales y oleaginosas más importantes $\left(15,2 \times 10^{6} \mathrm{Mg}\right.$ año $\left.0^{-1}\right)$ y el biodiesel y bioetanol de soja y maíz, suministrarían 295.383 TJ. Los residuos aportarían potencialmente el 72,1\% (32,4 x $10^{6} \mathrm{BP}, 282,9$ PJ o $\left.45,6 \times 10^{12} \mathrm{kcal}\right)$ y los biocombustibles el $27,9 \%$. La extracción de los residuos para tal fin tendría consecuencias riesgosas para la sustentabilidad de la productividad agropecuaria, principalmente sobre la conservación de los suelos y la estabilidad de los sistemas de producción. Es muy importante explorar otras fuentes alternativas como cultivos bioenergéticos o plantaciones de especies arbustivas o arbóreas, antes que el uso de los residuos de cosecha.
\end{abstract}

Palabras clave: Bioenergía, biocombustibles, residuos de cosecha, sustentabilidad.

\section{References}

Alvarez, R. 2001. Estimation of carbon losses by cultivation from soils of the Argentine Pampa using the Century model. Soil Use \& Management $17: 62-66$

Alvarez, C. and M. Barraco. 2005. Efecto de los sistemas de labranza sobre las propiedades edáficas y rendimientos de los cultivos. Boletín $\mathrm{N}^{\circ}$ 4. Indicadores de calidad física de suelos. EEA INTA Villegas. p 5-14.

Andriulo A. and G. Cordone. 1998. Impacto de labranzas y rotaciones sobre la material orgánica de suelos de la región pampeana húmeda. In: J. Panigatti, H. Marelli, D. Buschiazzo and R. Gil (Eds.). Siembra directa, Buenos Aires, Argentina. p. 65-96.

Argonne National Laboratory. 2005. Ethanol study: key points. Office of Energy Efficiency and Renewable Energy. US Department of Energy. US.

Blanco-Canqui, H.and R. Lal. 2006. Soil and crop response to harvesting corn residues for biofuel production. Geoderma 141:355-362.
Bolsa de Comercio de Santa Fe. 2009. Centro de Estudios y Servicios. Base de datos. Gobierno de Santa Fe, Argentina. http://www.bcsf.com.ar/ces/estadisticas.php (Consultado el 12 de enero, 2009).

Carter, M.R. 2002. Soil quality for sustainable land management: organic matter and aggregation interactions that maintain soil functions. Agronomy Journal 94:38-47.

FAO, 2006. Plataforma Internacional de Bioenergía. Roma, Italia. http://www.fao.org/sd/dimen2/ en2060501es.htm (Consultado el 6 de enero, 2009).

Fischer, G. and L. Schrattenholzer. 2001. Global bioenergy potentials through 2050. Biomass and Bioenergy 20:151-159.

Franzluebbers, A.J. 2002. Water infiltration and soil structure related to organic matter and its stratification with depth. Soil \& Tillage Research, 66:197-205.

García, F. 2007. Intensificación Ecológica de los Sistemas de Producción de la Región Pampeana de Argentina. XVII Congreso Latinoamericano de la Ciencia del Suelo. SLCS . León, Guanajuato, México. 334 pp. 
Giunta, R.C. 2007. Aptitud potencial y uso de los suelos santafesinos con biocombustibles. XV Simposio Electrónico Internacional. Chubut, Argentina. $6 \mathrm{pp}$.

Graham, R.L., R. Nelson, J. Sheehan, R.D. Perlack, and L.L. Wright. 2007. Current and potential U.S. corn stover supplies. Agronomy Journal 99:1-11.

Gupta, S.C., C.A. Onstad, and W.E. Larson. 1979. Predicting the effects of tillage and crop residue management on soil erosion. Journal Soil \& Water Conservation 34:77-91.

Jingura R.M. and R. Matengaifa. 2008. The potential for energy production from crop residues in Zimbabwe. Biomass and Bioenergy 32:1287-1292.

Lal, R. 1995. The role of residue management in sustainable agricultural systems. Journal of Sustainable Agriculture 5:51-78.

Lal, R., R.F. Follett, J.M. Kimble, and C.V. Cole. 1999. Managing U.S. Cropland to sequester carbon in soil. Journal of Soil \& Water Conservation 54: 374-381.

Lal, R. 2004. Soil carbon sequestration impacts on global climate change and food security. Science 304:1623-1627.

Lal, R. 2005. World crop residues production and implications of its use as a biofuel. Environment International 31: 575-584.

Lal, R., 2006. Enhancing crop yields in developing countries through restoration of the soil organic carbon pool in agricultural lands. Land Degradation \& Development 17:197-209.

Lal, R. and D. Pimentel. 2007. Biofuels from crop residues. Soil \& Tillage Research 93:237-238.

Larson, W.E., J.B. Swan, and F.J. Pierce. 1982. Agronomic implications of using crop residues for energy. In: Lockertz W, editor. Agriculture as a producer and consumer of energy. AAAS Selected Symposium 78: 91-122.

Linden, D.R., C.E. Clapp, and R.H. Dowdy. 2000. Long-term corn grain and stover yields as a function of tillage and residue removal in east central Minnesota. Soil \& Tillage Research 56:167-74.

Mae-Wan, H, P. Bunyard, P. Saunders, E. Bravo, and R. Gala, R. 2006. Which Energy?. Institute of Science in Society Energy Report. London, UK. $71 \mathrm{pp}$.

Mann, L., V. Tolbert, and J. Cushman. 2002. Potential environmental effects of corn (Zea mays L.) stover removal with emphasis on soil organic matter and erosion. Agricultura, Ecosystems \& Environment 89:149-166.

Montico, S.; Bonel, B.; Dileo, N.; Denoia, J. 2007. Gestión de la energía en el sector rural. Ed UNR. Rosario, Argentina. 204 pp.

Mubarak, A.R., A.B. Rosenani, A.R Anuar, and S. Zauyah, S. 2002 Decomposition and nutrient release of maize stover and groundnut haulm under tropical field conditions of Malaysia. Commun Soil Science \& Plant Analisys 3:609-622.

Nelson, R. G. 2002. Resource assessment and removal analysis for corn stover and wheat straw in the Eastern and Midwestern United Statesrainfall and wind-induced soil erosion methodology. Biomass \& Bioenergy 22:349-63.

Nonhebel, S. 2007. Energy from agricultural residues and consequences for land requirements for food production. Agricultural Systems 94:586-592.

NCCE. 2008. Conversion Factors for Bioenergy. Woody Biomass: Nature's renewable energy. WB-0008.North Carolina, US.

NREL. 2006. From Biomass to Biofuels. Department of Energy Office of Energy Efficiency and Renewable Energy by Midwest Research Institute, $6 \mathrm{pp}$.

Patrouilleau, R.D., C. Lacoste, P. Yapura, and M. Casonotas. 2006. Perspectivas de los biocombustibles en Argentina, con énfasis en el etanol de base celulósica. INTA. Informe Final. 70 pp.

Patzek T. and D. Pimentel. 2005. Thermodynamics of energy production from biomass. Critical Reviews in Plant Sciences 24:327-364.

Pimentel, D. 2003. Ethanol fuels: energy balance, economics and environmental impacts are negative. Natural Research 12:127- 34.

Quiroga, A., O. Ormeño, and N. Peinman. 1998. Impacto de labranzas y rotaciones sobre la material orgánica de suelos de la región pampeana húmeda. In: J. Panigatti, H. Marelli, D. Buschiazzo and R. Gil (Eds.). Siembra directa, Buenos Aires, Argentina. p. 57-65.

Razo, C., S. Astete-Miller, A. Saucedo, and C. Ludeña. 2007. Biocombustibles y su impacto potencial en la estructura agraria, precios y empleo en América Latina. CEPAL-Serie Desarrollo Productivo $\mathrm{N}^{\circ}$ 178. Santiago de Chile, Chile. 47 pp.

Secretaría de Energía Argentina. 2008. Matriz de oferta y demanda de bioenergía. Situación actual y desarrollo potencial en Argentina. Documento Taller. $21 \mathrm{pp}$. 
Sheehan, J., A. Aden, K. Paustian, K. Killian, J. Brenner, and M. Walsh. 2004. Energy and environmental aspects of using corn stover for fuel ethanol. Journal of Industrial Ecology 7:117-46.

Stout, B. A. 1990. Handbook of energy for world agriculture. New York: Elsevier Science; 1990. $504 \mathrm{pp}$.
Strehler, A. and G. Stutzle. 1987. Biomass residues. In: Hall D.O.; Overend, R. P., editors. Biomass: regenerable energy. London: Elsevier 75-102.

Wilhelm, W.W., J.M.F. Johnson, J.L. Hatfield, W.B. Voorhees and D.R. Linden. 2004. Crop and soil productivity response to corn residue removal: a literature review. Agronomy Journal 96:1-17. 
